\title{
Misdiagnosis of type 1 diabetes mellitus
}

\author{
Noor Shafina Mohd Nor ${ }^{1^{*}}$, Muhamad Yazid Jalaludin², Fatimah Harun ${ }^{2}$ \\ From 7th APPES Biennial Scientific Meeting \\ Nusa Dua, Bali. 14-17 November 2012
}

\section{Introduction}

In the past type 1 Diabetes Mellitus is the commonest type of diabetes affecting children in Malaysia. Nevertheless, diagnosis of type 2 Diabetes Mellitus is increasingly being made due to the rising prevalence rate of obesity amongst children. This contributes to the difficulty in making the right diagnosis at initial presentation if the clinical features that distinguish the two overlap.

\section{Case}

An $8 \frac{1}{2}-$-year-old Indian boy is reported here to have been mistakenly diagnosed as type 2 Diabetes Mellitus. He initially presented with a 2-day history of polyuria, polydipsia and nocturia. Initial screening of random blood glucose (RBG) at a local pharmacy reported the blood glucose $(B G)$ as high $(27 \mathrm{mmol} / \mathrm{L})$. He then presented to the emergency department where the BG was $25.1 \mathrm{mmol} / \mathrm{L}$ without metabolic acidosis $(\mathrm{pH} 7.404$, bicarbonate $23.0 \mathrm{mmol} / \mathrm{L}$ ). Serum ketones was $0.8 \mathrm{mmol} / \mathrm{L}$. Paternal and maternal grandparents have type 2 Diabetes Mellitus diagnosed in adulthood. He was overweight with BMI of $19.5 \mathrm{~kg} / \mathrm{m}^{2}\left(90^{\text {th }}\right.$ perdentile). Examination revealed acanthosis nigricans on the neck and the axillae. An initial diagnosis of type 2 Diabetes Mellitus was made. The HbA1c was $11.2 \%$ and C-peptide $0.8 \mathrm{ng} / \mathrm{mL}$ (Normal 0.9$4.0 \mathrm{ng} / \mathrm{mL}$ ). He was started on Metformin $250 \mathrm{mg}$ daily with the aim of slowly increasing the dose. His BG continued to be between $18.8 \mathrm{mmol} / \mathrm{L}$ and $27.3 \mathrm{mmol} / \mathrm{L}$ pre-meals with pre-breakfast BG around 13 to $14 \mathrm{mmol} / \mathrm{L}$. He continued to have ketonemia (serum ketones between 0.5 and $1.3 \mathrm{mmol} / \mathrm{L}$ ) without metabolic acidosis. Hence, basal subcutaneous insulin was added $(0.4 \mathrm{unit} / \mathrm{kg} /$ day) 3 days after starting Metformin. His BG improved and he was discharged home. On review four weeks later, he had few episodes of mild hypoglycaemia with Metformin $500 \mathrm{mg}$ BD and Glargine 8 units $(0.25$ units $/ \mathrm{kg} /$ day $)$ at bedtime. His diagnosis was revised to type 1 diabetes

${ }^{1}$ Faculty of Medicine, University Teknologi MARA, Selangor, Malaysia Full list of author information is available at the end of the article mellitus as his auto-antibodies were markedly elevated i.e. anti-Glutamic Acid Decarboxylase (GAD) $>2099.75 \mathrm{U} / \mathrm{ml}$ $(<10 \mathrm{IU} / \mathrm{ml})$, anti-Islet Cell (ICA) $22.06(<0.7)$ and anti-IA2 153.91U/ml $(<10 \mathrm{IU} / \mathrm{ml})$.

\section{Conclusion}

Making the correct diagnosis of diabetes mellitus in children based solely on clinical phenotype i.e BMI and presence of acanthosis nigricans is no longer reliable. Additional laboratory tests namely C-peptide and elevated auto-antibodies and response to initial treatment are essential to aid in our clinical judgement and correct treatment.

\section{Authors' details \\ ${ }^{1}$ Faculty of Medicine, University Teknologi MARA, Selangor, Malaysia. ${ }^{2}$ Faculty of Medicine, University Malaya, Kuala Lumpur, Malaysia.}

Published: 3 October 2013

doi:10.1186/1687-9856-2013-S1-P23

Cite this article as: Nor et al:: Misdiagnosis of type 1 diabetes mellitus. International Journal of Pediatric Endocrinology 2013 2013(Suppl 1):P23.

Submit your next manuscript to BioMed Central and take full advantage of:

- Convenient online submission

- Thorough peer review

- No space constraints or color figure charges

- Immediate publication on acceptance

- Inclusion in PubMed, CAS, Scopus and Google Scholar

- Research which is freely available for redistribution 